\title{
A Lacanian Reading of the Poem of "On Chilliness Inside" by Ahmad Shamloo
}

\author{
Narges Moradi \\ University of Guilan, Iran \\ Ali Taslimi \\ University of Guilan, Iran \\ Mohammad Ali Khazane Darloo \\ University of Guilan, Iran
}

\begin{abstract}
Lacan links psychoanalysis and linguistic to explain the unconscious manner, using the theories of Freud and Ferdinand de Saussure. According to Lacan's view the unconscious manner, is the basic of the existence and it forms from childhood. The subject" or the Child, enters to "The symbolic order", after crossing "The imaginary order". In "The symbolic order", "The subject" experiences the "Lack" of union of the mother. "The subject" tries to return to childhood and the first companion form, but in "The symbolic order" it is not possible, as the establishment of the language and its domination on the child dictates such a behavior. There for "the subject" by appealing to "The object petite" like "Love" and "beloved" tries to approach to "the imaginary order". This article first inspects Lacan's verbal unconscious theory about "The subject", then how this theory will become the concept of the poem of Ahmad Shamloo," On Chilliness Inside".
\end{abstract}

Index Terms - Lacan, Ahmad Shamloo, the imaginary order, the symbolic order, beloved

\section{INTRODUCTION}

Ahmad Shamloo (December 12, 1925-July 24, 2000) is an Iranian poet, author, journalist, researcher, translator and lexicographer. His fame is due to his creativity in Persian contemporary poetry especially a kind of free verse known in Persian as Sepid Persian Poetry (literary meaning white) or Shamlooian Poetry. Shamloo published sixteen volumes of poetry all of which have been translated into several languages. Love, life and humanism are among dominant characteristics of his poetry. Shamloo's love poems are one of the most beautiful works in modern Persian literature which are mostly written in a flash of inspiration. To be more precise, there is almost no time span between thinking and reciting poetry. Moreover, his poems, in contrast to his contemporary poets such as Mehdi Akhvan-Sales, were not revised, edited or changed for publication. He believed that the first draft of a poem should be the final draft and it is because of the same reason that he preferred prose to verse since thinking about rhythm and rhyme imposes limitation on the language of poetic thought. Shamloo used to develop an idea in his conscious, semi-conscious and unconscious mind which erupted as a volcano while he was reciting poetry. So his poetry is a good example that can be analyzed for slips of tongue.

This article focuses on latent ideas in underlying layers of "On Chilliness Inside". The poem has psychological themes and it suits Lacanian analysis.

\section{METHODOLOGY AND APPROACH}

This research is based on psychology approach to Lacan's Theory and helps dipper understanding of text glob by qualitative content approach using Lacan's Ttheory. In other words, in this paper, A framework is made on Lacanian psychoanalysis which are follow in signs language and visual narrative poem "On Chilliness Inside ". Obviously, in this analytical approach, not all details but most important of Lacanian psychoanalysis have been included.

The theoretical principle of Lacanian psychological Development of a Subject

Jacque Lacan (1981-1901) is one of the French contemporary psychoanalysts and philosophers who has been very influential in developing Freud's psychoanalytic theories. Lacan is famous for applying Saussarian linguistics to psychoanalysis especially to unconscious. One of the ramifications of such a mix is that "unconscious has a lingual structure" (Ward, 2004, p.199). What distinguishes Lacan from post-Freudian psychoanalysts is his particular emphasis on language. The major ground for cognitive understanding of human being and its world is the growth of a child in relationship with his mother, father and others. The real order, the symbolic order and the imaginary order constitute the tripartite scheme at the center of Lacan's thought. According to Lacan, the real order happens before language acquisition while the symbolic order is the time when human being learns language. Lastly, the imaginary order begins with the symbolic order and they continue side by side for the rest of life. 


\section{The Real order}

The real order lacks clarity in Lacan's works. Similarly, what other researchers said about it is puzzling and complicated; it just touches some parts of the concept. Such bafflement is the result of Lacan's complicated philosophical language rather than his cognitive approach. However, as Klages states "an infant who only has attainable needs and makes no distinction between itself and what satisfies its needs, according to Lacan, is in real order. The real order is a mental center which has primary unity. This is why there is no absence, lack or loss in the real order" (Klayges, 2009, p.115-116). In this stage, when an infant does not feel any absence or loss the infant has not discovered itself yet; the infant only touches its body and its mother's breast. It is through touch that the infant feels disintegrated and fragmented body which are all considered as another. In other words, the infant is unable to recognize itself.

\section{The imaginary order}

The imaginary order as the name suggests is the time of illusion, fascination and seduction. It is the time when an infant identifies itself with its mother. The closeness of an infant to its mother during pre-lingual stage creates the illusion that the infant body and its mother are the same. The result of such a stage is unity, happiness and satisfaction (Payandeh, 2009, p.30). "The mirror stage" which happens throughout the imaginary order is a stage for selfrealization of an infant. An infant sees itself in the mirror and goes beyond the real since it is using its vision. The vision, in contrast to touch, is holistic. Therefore, against the real when the mirror stage is not undergone, it comes to its selfrealization after eighteen months; but still it can distinguish between itself and the other especially the mother. In other words, according to Freud, an infant cannot make a distinction between a subject and an object or between itself and the reality. This is what Lacan calls the imaginary order. In the pre-Oedipal stage, the infant has not accepted the father's presence, just lives with its mother and cannot recognize a clear distinction between itself and its mother so it only sees itself and its mother; but when it grows older and more recognizes the outside world it sees the father intervention in this relationship.

\section{The symbolic order}

The infant understands that its mother, who was part of it, has been disintegrated for the sake of father and there is a gap between the former and the latter. As Lacan states father (or the-name-of-father) is the founder of the primary privations: the privation of incest. The infant has to suppress its pleasure of first object of desire, mother, and it leads to unconscious. This is the oedipal stage which Lacan calls it the symbolic order. The oedipal stage begins during the time of language development in an infant. To be more precise, when desires are suppressed to be channeled into unconscious, it is the time of language development in an infant. Language is the annihilation of the subject and object relationship or human being and the outside world. As a result, the infant loses its unity with mother and mirror. The infant knows that the one whom it sees in the mirror is not the infant itself but it looks like the infant. It is in this stage that the symbol making process and the concept of other especially mother as the other (lack or absence of mother) is created and at the same time, the infant confronts the return of the desire for mother. The infant who used to see mother as part of itself and mother "mirror" itself, it is now entered the unknown realm of language where the bond between signifier and signified is arbitrary.

The infant post-structural anxiety is due to its vulnerable identity in "mirror" of mother which is now lost in mirror of language and it undergoes changes. It is because the infant must have led all its libidinal drives and desires to unconscious in pre-lingual stage and sees itself in relationship with others. In other words, the signified of its identity is changed in connection with those of others. One of such first changes is because of father, the fear of castration, which leaves a gap between the lawless and fragmented imaginary world of desire of mother and infant several identities (see Lacan, 1988, p.166).

\section{Little Other ${ }^{1}$ and the Other ${ }^{2}$}

The infant has a fragmented or divided perception of itself. Different parts of its body are separated. Such fragmentation or disintegration ends when the infant enters a "mirror stage" (Payandeh, 2009, p.30). It is because at this stage (sixth to eighteenth month) the infant gets used to others defragmented image of body and its own image in the mirror (which is the image of the other) and so it recognizes that its body is different from its mother's. Such understanding breaks the dyadic mother/child relation and the child desires to return to mother again (Easthope, 2005, $p$. $82,86,128)$.

The infant tries to identify its desire with that of mother since it thinks that it can take the mother's object position but after a while it finds out mother desire is towards father (the other Other) and as a result it recognizes the object of father and his part in mother's satisfaction (Movallai, 2006, p. 100). This is the stage when Freud calls it oedipal while Lacan names it "the Name-of-the Father".

The infant confrontation with Name-of-the Father (the other Other or the first other) and the fear of castration make the infant ignore the mother and enters the symbolic order world. "Indeed, the psychological significance of father for the infant who has entered the symbolic order is the presence of an authoritative person who plays the role of a subject in society. Now the infant should learn that there is a wider realm than that of the family whose first and most fundamental rule is privation of incest. The patriarchal structure of culture is the reason behind the socialization of the

\footnotetext{
${ }^{1}$ Object petit a

${ }^{2}$ Object petit A
} 
infant due to father's (not mother's) privations (Payandeh, 2009, p. 32) and as a result, "the Other" is the society where through its privations the infant enters the symbolic order (see.Kadivar, 2002, p.63).

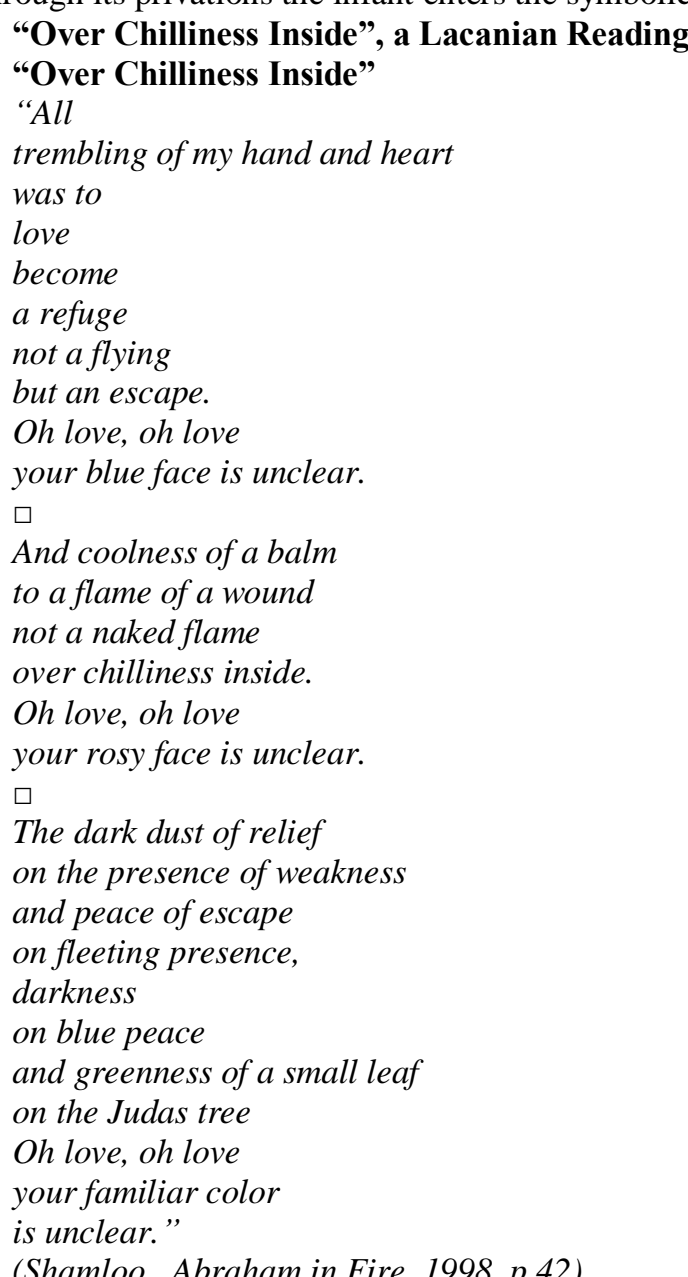

(Shamloo, Abraham in Fire, 1998, p.42)

Three interpretations:

In the first part of the poem, what worries the poet is that love to be his refuge and escape; while what he is willing is flying. He is seeking a redeeming love to free him from captivity. He likes flying but he is afraid that such a love would not be redeeming.

In the second part, the poet likes that the love to be a naked flame over chilliness inside not a balm to his wound but all his fears and worries that it would be so; he likes it to be a relief not a cure. In the final part, the poet does not use the conjunctive "and"; in other words, he comes to a conclusion that despite all this attempt he gained nothing: "the black relief on worthless existence and corner to flee the existence and fertile presence" (Taslimi, 2009, p.113). Shamloo is seeking a redeeming love in these three parts. However, the question is whether such a love which the poet is willing is possible?

The relationship between the lover and beloved in different epochs of lyrical poetry had been static and repeated. The image of beloved in lyrical poetry is a general image to the extent that it is difficult to distinguish whether it is male or female. The beloved is a sacred and unattainable creature who is brutal, tyrannical and blood-thirsty and suffers sadism. On the other hand, the lover is masochistic who enjoys the brutality of his beloved (Shaf'ie, 2001, p.23).

"The image of thy sword is the story of a thirsty and water / had you owned your slave kill him as thou wish."

(Hafiz, 2001, p.403)

The love in Sufism is a hardship itself and its consequence is the ignorance of the lover of the outside world. As Ahmad Ghazali states, "love of whatever kind is sacred as such if the beloved is lover's captive she is still superior to the lover" (Dehghanipoor, 1998, p.123). Therefore, love ends in captivity and the lover is in need, admires coyly beloved, becomes her slave and tolerates all her tyranny ${ }^{3}$ :

"S'addi from the lock of the beautiful / thou are alive, thou cannot escape."

(S'addi, 1992,p.144)

"Like a deer I escaped the lion to desert / that lion took me to mountain while hunting."

(Molavi, 1999, p.58)

${ }^{3}$ Disdain and poverty are among religious terminology which is equivalent of coy in literature. 
"My trap is her hair, her mole is the seed, and I In search of those seeds have been trapped by my friend."

(Hafiz, 2001, p.81)

So the love is not the reason for freedom, escape and flying. However, some poets used such a theme like S'addi:

"Since the day I am enslaved I am freed / I am the king who is your captive."

(S'addi, 1992,p.418)

Or Hafiz who borrowed such theme from S'addi:

"Hafiz will embrace your oppression / was freed since enslaved in this fashion."

(Hafiz, 2001, p.217)

In Rumi's poetry such themes can be seen as well:

"Look at me who saw thousands freedom / since my soul and body are love's captive and slave."

(Molavi, 1999, p.419)

Such freedom and liberty through captivity is impossible and is paradoxical, indeed. Since the necessity of love is captivity or at least it is so in earthly love. Shamloo in this poem, which deals with an earthly love, how claims freedom. Such claims is valid as far as the poet to be beloved himself. In classical Persian poetry, the beloved of each era is subordinate to the values of beloveds of previous poets; such subordination is not just seen in aesthetic of its poetry but includes individual characteristics such as disloyalty, coyness, vanity and irascibility. Coyness is one of the common characteristics of the beloved and obedience is that of the lover.

"The lover and beloved differ as white and red/Need your hunger, when beloved wants to be fed."

(Hafiz, 2001, p.221)

"The unity of you and me are belated / since I am slaved to you and you are the owner of coy."

(S'addi, 1992,p.602)

It should be born in mind that the lovers are in state of contraction. Among Persian poets it is only Rumi who is in state of coy; Rumi considers himself as God's beloved since he is in expansion state while lovers are in contraction state. There are several poems which bear testimony to Rumi's state of expansion:

"Freed of poverty and need / dancing toward coyness."

(Molavi, 1999, p.1670)

There is relationship between Shamloo's unconscious and free association this poem; unconsciously, Shamloo has stated that he mostly likes to be a beloved. His love is one-sided love and for his benefit. In Shamloo's unconscious, there is motherly desire to be himself a beloved and the other to be a lover.

Since his early days and his first collections of poetry, Shamloo was in search of an ideal beloved; it is to such extent that not his youngish love (Galia's love), not his marriage with Ashraf Islamieh, a young teacher who born him four children named Siavash, Sirous, Saman and Saghi, not his second marriage with Tousi Haeri lasted for four years; not the short and endless loves that he made during his life as the sources of inspiration for some his poems were ideal. "These are women who bear no motherly affection and regardless of their maternal passion and affection they wanted him for himself and their own satisfaction" (Farokhzad, 2004, p.47). Even deep and immense love of Aida which brought peace to troubled life of Shamloo could not be replaced by the love of his mother:

"Tired, tired, I am coming from the by-ways of doubt

like a mirror I am full of you

nothing can relieve me

not the stalk of your arms,

not the springs of your body

it needs nothing, it cannot relieve me

...let me be familiar with you my stranger

lets be oneself."

(Shamloo, I Say Hi to You. Part One, 1998, p.216, 217)

"With your eyes and lips, I have grown fond

I have grown fond of your body

something came down in me

something bloomed in me

I fall asleep in my childhood cradle

and the smile of that time

regained

...your hands like a spring flows to me

and I am new I am assured

I hugged the assurance as a doll

and I was slept in the cradle of my early days

in your lap which was the cradle of my dreams

and the smile of those days returned to my lips

with your body you told a lullaby for my body

your eyes were with me 
and I closed my eyes

since your hands were trusty."

(Shamloo, Resources, Part One, 1998, p.221,222)

"And among all the women who opened new doors to him, he never felt the warmth of his mother's womb; not the Kokab, his mother, who gave birth to him in the snowy day of 12 December, 1925 in No. 134, Safialshah St., neither his eternal and ideal mother who lived in the deep layers of his mind and was the source of all kindness and affection...or the woman of his self-image, Roxana, the hidden female half of the poet is in reality the symbol of his archetypal eternal woman-mother" (Farokhzad: 2004, p.55) could be replaced by the warm lap of his mother.

There is a motherly desire in Shamloo's unconscious that he is beloved and the other is lover. The love is a maternal love; "mother is usually closer to the child and the child is vulnerable; the child is free and destructive and love of mother is only love that can make human free. He is in search of a beloved who is like mother. The love that according to Lee's love styles" is a kind of "Agape"; it's a combination of "Eros" and "Storge". The maternal love is a kind of flip and a sort of force to look after the child; a beloved like a mother who is an unconditional and perfect love from all aspects.

In his book, The Art of Loving, Erich Fromm, believes that the fatherly love is a conditional love. The children can get it according to some necessities. The father love the son who meets more of his expectations. On the other hand, there is a motherly love who is shared among all her children and this love is because it is toward her children (quoted in Eshraghi, 2007, p.48).

"Both Freud and Lacan regard being in love as an expression of narcissism, not love for the other but self-love, selfdeception." (Easthope, 1382, p.94). Since in my ideal, whatever is done by my beloved and whatever she likes is desirable. For Lacan, to love is the desire to be loved (Lacan, 1977, p.253). Here love is one-sided for the interest of subject/poet and in his unconscious it is maternal that "Lacan calls it "the other little object" (versus "Other" which is the symbolic order)" (Shiri, 2011, p. 89). So, Shamloo decides to be a beloved and the other his lover. The belovedmother is usually the desire which its object is mother. Shamloo's image of the beloved is maternal, that is, he passes "the imaginary order" and pre-oedipal stages and his unity with mother is disintegrated. However, "according to Lacan such independence does not happen in reality. The nature of being, that is, achieving a wholeness free from others, especially from mother. Mother and child are not separated identities in "the imaginary order". Penetration of the child's identity in mothers gives the child a sense of safety which we all seek it, knowingly or unknowingly, in later stages in our life but we do not find it.

The child desire to overcome the departedness of "self/other" and the lost unity with mother will remain in the unconscious and later it may emerge in strange forms. The subject represses the desire to return to childhood of "the imaginary order"; but he cannot ignore such dark side of himself. Despite the dominance of "the symbolic order", "the imaginary order" still calls us to itself like a mirage" (Payandeh, 2009, p. 35).

But it is the fear of passing "the imaginary order" to "the symbolic order", that is, transformation from pre-oedipal to oedipal. He is afraid of losing love or his love and beloved-mother to be captured by the other. Now, Shamloo "represses" his desire for mother, the desire to incest, due to fear of "castration" and it ends in his unconscious; then such transcendental desire is sublimed and it goes to somewhere else whose characteristics is to be beloved. "Refuge" and "escape" which is associated with mother's lap and also, "peace", "relief" and "balm" are all among the characteristics of a mother. Willing mother's abundant presence in fearless moments and the worries of "the symbolic order" is the oedipal concern of the poet.

The blue colour which is among the cold colour groups refers to silence and permanent peace; blue is the symbol of inspiration, sacrifice, peace and loyalty. Such colour can be used in treating anxiety and heart palpitation (see Williams, 1996). Also, blue is the symbol of water, peaceful nature of human and female nature (see K. Lusher, 1993). Which is relevant to pre-oedipal and pre-lingual stage. It represents the unity of mother and child before entering "the symbolic order". Among the geometric shapes, the blue colour is compared with a circle which is like sky. Circle is like an oval without any corner which never distracts the viewer (Khajeh pour, 2010, p.24).Circle used to refer to old times is the reminiscent of those memorable old days of peace (the imaginary order and pre-oedipal in this case) which is lost. The red is the colour of passion; the colour of heart and flames of fire which symbolises lust, danger, warmth, sincerity,

\footnotetext{
${ }^{4}$ According to Lee's love styles theory, there are different views of love which are influenced by emotions, family experiences and behaviors. The six love styles are divided into groups of primary and secondary loves:

a) The primary love styles

1. Eros: it is a severe emotional experience which is like the erotic love and one of its significant characteristics is its immediate attraction for loving (see Lee: 1988).

2: Loudos: is one of the kinds of love play. Loudos lovers are skilled players and they have several love partners (ibid).3: Storg: it is a kind of love which decreases stress and psychological pressure and it necessitates deep love and responsibility. This kind of love is a life-long friendship which is trust-worthy and does not emphasise love (see Fricker\& Hons: 2006).

b) The secondary love styles:

1. Pragma: it is combination of "Storg" and "Loudos". This kind of love gives much value to the love partner. The pragmatic love has a practical approach is looking for a compatible love. (ibid)

2. Mania: this kind of love is combination of "Eros" and "Storg". A combination of possessiveness and worriment (see Hendrick \& Hendrick,1987).

3. Agape: the last kind of love styles, a combination of "Eros" and "Storg". This kind of love is magnanimous and self-sacrificing; the Agapic lovers which to take care of their lovers without any expectations. Agape requires sacrifice, honesty and support. (see Lee: 1973 \& 1977).
} 
generosity, ambition, devotedness, optimism, cheerfulness and energy. It is more piercing colour than any other colours (Chi Gi Va, 1998). Red colour stimulates the "fire inside" which is a necessary warmth for life survival. It attracts many and it is the first colour the infant recognises.

When the love wants to show its red face it is more oedipal in this poem. In the first and second parts, Shamloo is looking for a love which "blue" or "red". But nobody shows its face to him and the poet is in the mid of pre-oedipal and oedipal stage since he wants to verify either the peaceful or erotic love but still none of them appear. Furthermore, at the end of the third part, "darkness" which is blackest of all colours and represents the absolute boundary where beyond it the life ends. So it connotes absurdity and futility (see Lusher, 1993) and later the "peaceful blue is replaced by it" and the redness of Judas tree is substituted with "the fleeting greenness of small leaf" and among all these colours the familiar colour of love is lost” (Taslimi,2009, p.113).

Addressing the love at the end of all three parts of the poem is an oedipal request which shows the search of subject/poet in finding "other little object" (the supporting mother). One of the most fundamental mechanisms of human psyche especially in dreams is "displacement". Humans, unconsciously, transform an emotion or symbolic meaning to another object (desire) in order to follow the same goal in another way (Payandeh, 2009, p. 44). The "the little other" is replaced by love while from the outset the poet knows that such separation is unavoidable since the love does not appear and its familiar colour is unclear.

\section{CONCLUSION}

"Subject of the enunciation" /poet is in unity with mother; then he is trapped in "the symbolic order" which is the time of dominance of language and separation from "the imaginary order". Now it is the time when he confronts a "lack". Later, the subject/poet suffers and he goes to the little other (love in this case). The subject/ poet who wants to be beloved so love to be liberating for him. What he seeks in love is affection and passion of mother; it is kind of love which supports him fully without any expectations. A kind of "Agape" which is one-sided and caring; it is combination of "Eros" and "Storg" and it is only through this kind of love that freedom and flying is possible for the subject/poet. The freedom which is remembrance of his unity and harmony with mother in "the imaginary order".

"Subject of the enunciation" or the poet in the form of love is looking for "the little other"/mother to answer his will as in "the imaginary order" and take him to the his childhood: pre-lingual and pre-oedipal stage when he has not learnt language and he was in close relationship with his mother, to the enduring love (the imaginary order), to those old days which was the time of happiness and peace. However, he regrets those days since gaining that lost time seems impossible. Subject/poet uses "displacement" mechanism to overcome separation while such departedness is not replaceable and cannot result in unity. Finally, "darkness" shadows "the blue peace" and "greenness of small leaf" dominates "Judas tree". A transitory relief is likely to happen to the subject but that familiar colour of "the imaginary order order" and unity is impossible. Lacan believes that subject/poet by sticking to this "little other" approaches "the real order" but such satisfaction is just a fleeting happiness and the primary unity is impossible.

\section{REFERENCES}

[1] Chijiwa, Hideaki. (1998). Color harmony (Translated by Feriyal Dehdashti \& others). Tehran: Karang Publication.

[2] Dehghani Poor,Mohammad. (1998). Temptations of lover, first edition,Tehran: Fall Program Publications.

[3] Easthop, Antony. (2011). The unconscious (Translated by Shiva Rouygarian) third edition, Tehran: Markaz Publication.

[4] Eshraghi, Mansore. (2007). Silent beloved, first edition, Tehran, Mina.

[5] Farrokhzad, Pooran. (2004). Mother's Christ, first edition, Tehran: Iran Jam Publication.

[6] Fricker, J. \& Hons, B. A. (2006). Predicting Infidelity: The Role of Attachment Styles, and The Investment Model.

[7] Hafez,khajeh Shams Aldin. (2001). Collection of poems, Corrected by Mohammad Ghazvini, Twelfth edition, Tehtan: Payam Edalat Publication.

[8] Hendrick , S. S. \&Hendrick, C. (1987). Love and Sexual attitudes Self - disclosure and Sensation Seeking. Journal of Social and Personal Relationships, 4, 281-297.

[9] Kadivar, Mitra. (2002). Lacan's doctrine, Tehran, Ettelaat

[10] Khajeh Poor, Milad. (2010). Colour; the psychology of life, first edition, Tehran: Sabzan Publication.

[11] Klages, Marry. (2009). A Guide for Perplexed (Translated by Jalal Sokhanvar \& Others), Tehran: Akhtaran Publications.

[12] Lacan, Jacques. (1977). Ecrits - A Selection, Trans. Alan Sheridan, London, Tavis Tock Publications.

[13] Lacan, Jacques. (1988). The seminar of J. Lacan Book II :The Ego in Freud,s Theory and in the Technique of Psychoanalysis 1954 -1955, translated by Sylvana Tomaselli , Cambridge , Cambridge University.

[14] Lee. J. A. (1973). The Colours of Love: An exploration of the ways of loving. Ontario, Canada : New Press.

[15] Lee. J. A. (1977). A Typology of styles of loving. Personality \& social psychology Bulltetin 3 (2). 173-182.

[16] Lee. J. A. (1998). Ideologies of lovestyle and sexstyle, In de Mank (Ed) Romantic Love and Sexual behaviours: Perspectives from the social science ( $\mathrm{pp}$.33-76). western port , connecticut: praeger.

[17] Luscher, Max. (1993). Color Test (Translated by vida abizadeh), Tehran: Dorsa Publication.

[18] Molavi Jalal Aldin. (1999). selection of shams's lyrics,(Selected by Mohammad Reza Shafiei kadkani), Tehran: Scientific \& Cuitural Publication.

[19] Movallali, KERAMAT. (2009). Introductions on Lacan psychoanalysis, Seventh edition. Tehran: Danjeh Publication.

[20] Payandeh, Hossein. (2009). Lacanian review of winter poem, Journal of Persian Language \& Literature, no 42, PP27-46.

[21] Saadi, Mosleh Aldin. (1992). Collection of lyrics, Second edition, Tehran: Koomesh Publication. 
[22] Shafiei Kadkani, Mohammad Reza. (2001). Periods of Persian poetry, Tehran: Sokhan Publication.

[23] Shamloo, Ahmad. (1998). Colection of Works, book one, Collected Poems, ninth edition, Tehran: Negah Publication.

[24] Shiri, Ghahraman \& others. (2012). From Lacan to Mollavi, Tehran: Persian literature journal of Azzahra University, Third year, no 6, pp 81-100.

[25] Taslimi, Ali. (2009). Literary Theory, First edition, Tehran: Ameh Publication.

[26] Ward, Glenn. (2004). Post modernism (Translated by Ghader Fakhre Ranjbari\& others). Tehran: Fish Publication.

[27] Wills, Pauline. (1996). Colour Therapy (Translated by Nasrin Faraji, Tehran: Dorsa Publication.

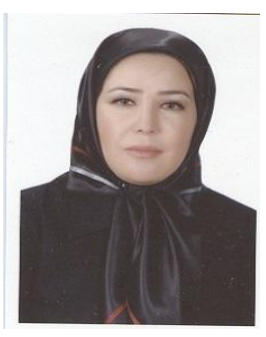

Narges Moradi was born in Chenaran, Iran in 1978. She received her MA. degree in Persian Literature from Al-Zahra University, Tehran, Iran in 2004.

She is currently a PhD. student in Faculty of Literature and Humanities, Guilan University, Rasht, Iran. Her research interests include Persian Language and Literature.

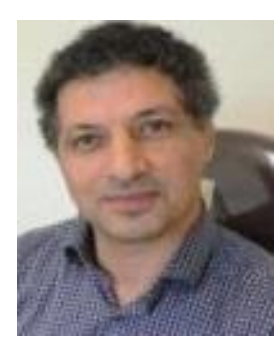

Ali Taslimi was born in Roudsar, Iran in 1961. He received his PhD. degree in Persian Literature from Tehran University, Tehran, Iran in 1991.

He is currently an associate professor in Faculty of Literature and Humanities, Guilan University, Rasht, Iran. His research interests include Persian Language and Literature.

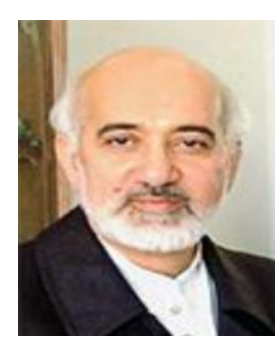

Mohammad Ali Khazane Darloo was born in Tehran, Iran in 1958. He received his PhD. degree in Persian Literature from Tehran University, Tehran, Iran in 1997.

$\mathrm{He}$ is currently an associate professor in Faculty of Literature and Humanities, Guilan University, Rasht, Iran. Her research interests include Persian Language and Literature. 